Patterns of Peaceful Cooperation in lhyā' al- 'Ulūm, Volume 21, Issue 1,

Medieval Muslim Medina and Its (Jan-June 2021)

Relevance to the Present

\title{
Patterns of Peaceful Cooperation in Medieval Muslim Medina and Its Relevance to the Present
}

* Dr. Farooq Hassan

\begin{abstract}
:
The Prophet Muhammad (PBUH) managed to reconcile multi-tribal, multireligious society of Medina by treating people with dignity and honour. He created a society without racism and racial superiority; it brought various faiths and flavors together and helped to remove barriers of tribal biases. The Prophet used nonviolent methods to resist those who persecuted him and considered peacemaking to be more effective than aggression and violence. Despite some clashes that took place between Muslims and Jews during domestic security arrangements in Medina, the Prophet (PBUH) welcomed the increasing racial and ethnic diversity and engaged in linguistic and cultural interactions. People of all colors felt safer under Muslim rule because there was no racism against blacks and no concept of white and Arab supremacy, Islamic philosophy has only two categories of human beings (believers and unbelievers). Dialogue begins when people meet each other and depends upon mutual understanding that is why the Prophet (PBUH) had frequent social interactions with people of different backgrounds and to improve the quality of relationships within local community, the Prophet (PBUH) explored different tools. This paper discusses the Prophet's (PBUH) attitude towards other communities and the nature of religious accommodation and coexistence.
\end{abstract}

Key words: Multiculturalism, diversity, Medieval Medina, peaceful coexistence, interfaith dialogue, Abyssinia, Islamic Pluralism

* Associate Professor, Department of Humanities, NED University Karachi 
Patterns of Peaceful Cooperation in lhyā' al- 'Ulūm, Volume 21, Issue 1,

Medieval Muslim Medina and Its (Jan-June 2021)

Relevance to the Present

Background: Revisiting Muslim past to connect with the realities of present, in order to interact appropriately with people of diverse backgrounds in different situations. As a Muslim minority, negotiating communication between people of different faiths is always complex, what were Islam's teachings about peaceful cooperation in a multicultural society on common issues? How different religions, races, tribes co-existed in Medina? This work focuses on the relationship between race and Islam.

\section{Introduction}

In pre-Islamic Arabia during annual fairs non-Makkans used to assemble in Makkah, where different people come into contact with different faith and races. Medieval Medina was an important city for a number of reasons as a Jewish business hub, pre-Islamic Arab slave trade centre, stopover and the intersection point for trade networks, pilgrimage routes etc., which provided them an opportunity to understand others. The people of Makkah had family ties with the people of Medina as Hāshim bin Abd al-Munāf, great grandfather of Prophet Muhammad (PBUH) married Salma bint-e-'Amr, a resident of Medina1 from the tribe of Banū Najjār. The Prophet's father Abdullah himself led commercial caravans northward, either into Persian or Byzantine territory, or into Syria. After one of his journeys, Abdullah fell ill, died and was buried in Medina. Abbas, uncle of the Prophet (PBUH) often visited Medina for trade. ${ }^{2}$ on an invitation from a small group of native Muslim Medinites (from Aws and Khazraj tribes), the Prophet Muhammad (PBUH) arrived at Medina in 622 A.D. Although Islam was gradually dominating by replacing the pagan religion of Arabia, there were other religions including Jews, Christians which lived throughout many cities of Arabian Peninsula. When conflict arose between them it greatly impacted people living in that region. ${ }^{1}$ Slavery existed throughout human history, it was practiced by every tribe, culture, racial group and religion, therefore, during the Battles in and outside of Medina, a number of solders were from various religions and races including high number of African slaves such as in the battle of Uhad (625 A.D), Wahshī, (a slave of Jubair b. Muta'am) ${ }^{3}$ and Sawab (a slave) both were originally from Abyssinia ${ }^{4}$ fought against Muslims. In the same battle Abu 'Uqba (R.A), one of the Persian companions ${ }^{5}$ and Mukhariq (a non-Muslim), ${ }^{6}$ supported the Muslim army. In the Battle of al-Ahzāb (625 A.D), Salman Fārsi, a Persian origin companion, whose Persian-oriented proposal for defense of Medina was also approved by Prophet Muhammad (PBUH). Abu Rafi, Ibrahim, a 
Patterns of Peaceful Cooperation in lhyā' al- 'Ulūm, Volume 21, Issue 1, Medieval Muslim Medina and Its (Jan-June 2021)

Relevance to the Present

freed slave of the Prophet (PBUH), had Coptic (Christian) background before Islam, was part of Muslim army in Uhud and Ahzab. ${ }^{7}$ In the Battle of Hunain (630 A.D) 'Uthman bin Abdullah fought against Muslims and was killed along with his Christian slave. ${ }^{8}$

\section{Existence of Multiple Religious And Cultural Traditions}

Medina was a city of people of different faiths and tribes, the Prophet (PBUH) pursued intertribal harmonious relations as he used their specific dialects to communicate as he (PBUH) said, "sal anka" (instead of "sal anma shi'ta" means ask whatever you want) which is the dialect of Bani Aamir" not to that of Quresh. The Prophet (PBUH) held a series of dialogue with more than a hundred delegations (some constituted hundreds of people) in very peaceful atmospheres. ${ }^{10}$ As a result, some dignitaries were so taken by the Prophet's conduct that they embraced Islam such as Jarūd b.in Bishr (or Amr), a representative of Bani Abdul Qais (a Christian tribe) ${ }^{11}$ and Adi bin Hātim (a Christian representative ). ${ }^{12}$ Mujebullah Nadvi has mentioned a list of 70 companions (63 male and 7 female) of the Prophet Muhammad (PBUH), who were Christians or Jews before embracing Islam. ${ }^{13}$ Abdullah b. Salam (d.663 A.D), a Jew of Banu Quynuqa tribe, Yamin b. Umair and Abu Sa'd bin Wahab, Jews of Banu Nadir tribe also accepted Islam. ${ }^{14}$ Asad b. Udaid and Thalaba bin Usaid were from Jewish backgrounds before embracing Islam. ${ }^{15}$ Jewish leaders and religious scholars used to ask questions to the Prophet (PBUH), and he addressed their questions via divine guidance from Allah. Unlike the Prophet ${ }^{(\mathrm{PBUH})}$, Jewish scholars did not entertain questions by the companions of the Prophet. When M'āz bin Jabal, Sa'd bin M'āz and Kharija bin Zaid asked some questions related to Torah, Jewish Scholars avoided answering them. ${ }^{16}$ In order to deal with the people and leaders from different backgrounds, some of the Prophet's companions were proficient in languages besides their native Arabic for example Zaid bin Thābit bin al-Dahhak bin Zaid al- Khazragi al-Najjari's (d.45/665), mother tongue was Arabic, he also knew Hebrew, Coptic and Persian languages. ${ }^{17}$ Abdullah bin 'amr bin al- 'Ās was also well versed in Aramaic language. ${ }^{18}$

\section{Jewish Tribes in Muslim Medina}

In spite of fighting with some Jewish tribes of Medina, the Prophet (PBUH) maintained peaceful relations with the Jewish inhabitants of the city. He (PBUH) married women of Jewish descent, such as Safiya bint Hyuui bin 
Patterns of Peaceful Cooperation in lhyā' al- 'Ulūm, Volume 21, Issue 1, Medieval Muslim Medina and Its (Jan-June 2021)

Relevance to the Present

Akhtab, ${ }^{19}$ and Raihana bint Umar. ${ }^{20}$ Why was co-existence with Medina's Jewish community important? One of the reasons is that in Medina, ArabicSpeaking Jews with Arab names made up a significant number, working as craftsmen, traders, farmers and Bedouins in urban and rural settings. Some records indicate that there were about twenty Jewish clans, of which Banū Nadhiar ( a tribe of date- farmers), Banū Qaynuqa (blacksmith and proficient warrior tribe) and the Banu Qurayza were prominent. Jewish communities who had been living with Aws and Khazraj (Ansars) for centuries and had marriages with them on social level, they also had very strong political and military relationships, as the Aws tribe was an ally of Banu Qurayza. Jews imparted their writing skills to children in Medina. Some from the Aws and the Khazraj tribes also learnt this art from Jews in pre-Islamic era ${ }^{21}$ Ubay bin Ka'b, Sa'd bin Ubadah bin Dulaym (d.14/635), al-Munzir bin 'Amr bin Khanis (d.4/626), all three al Ansar, belonged to Khazraj tribe and were capable of writing in Hebrew and Arabic languages. ${ }^{22}$

Islam and Judaism have monotheistic ties with many other similarities, the Prophet (PBUH) tried to accommodate the Jewish community in many ways. For about 17 months, Muslims and Jews shared a common Qibla (prayer direction), observed a common fast and certain standard dietary restrictions (e.g. not eating pork). The Prophet Muhammad (PBUH) entered into an alliance (Charter of Medina) with the Jews, which brought peace and pluralism through respect, acceptance, and denunciation of war. Examining some of the clauses in the Charter also shows how the Prophet managed to create harmony. The first clause of the Charter states "They are a single community (ummah)", ${ }^{23}$ that derived from the Qur'an (2:213) which reveals that "the people are one community". It illustrates the main goal of the rest of the Charter. Clause 25 refers to the Prophet's high level of acceptance of others. "The Jews... are a community (ummah) along with the believers. To the Jews their religion (din) and to the Muslims their religion" ${ }^{24}$ this statement ties in with many verses from the Qur'an, such as (Quran 109:5) "To you be your religion, to me be mine." Sachedina writes that, "(109:5) the Prophet responded creatively to those formative moments in the growth of intercommunity relations between Islam and other religions of the Book." 25 and (Qur'an 2:256) says, "There shall be no coercion in the matters of faith". Clause 25 also admonishes Muslims not to impose Islam upon people of Medina. 
Patterns of Peaceful Cooperation in lhyā' al- 'Ulūm, Volume 21, Issue 1, Medieval Muslim Medina and Its (Jan-June 2021)

Relevance to the Present

The Prophetic tradition stressed on respects of humanity and did not allow any prejudice against non-Muslims. Whenever a funeral has procession carrying the bier of a deceased passed by, the Prophet (PBUH) used to stand for it (out of respect). He was informed by someone that "O Messenger of Allah, it is the funeral of a Jew", to which he replied: "Is it not a soul"(means that a Jew is also a human- being). It clearly proves that the Prophet (PBUH) focused on sanctity and commonalities among all humans. ${ }^{26}$ the legacy of honoring human soul was continued by companions of the Prophet as Sahl bin Hunaif and Qais bin Sa'd did in Qadsia. ${ }^{27}$ Muslims and non-Muslims in need benefited from charity of Bait al-Mal, the Prophet helped in the welfare of a Jewish family which continued even after his demise. ${ }^{28}$ Same spirit of intercultural harmony could be witnessed in the lives of the wives of the Prophet and his companions. Once a Jewish woman came to Aisha (R.A.), wife of the Prophet (PBUH), and made a request for something. Ayesha entertained her request. In gratitude the Jewish woman prayed for Aisha. ${ }^{29}$ Safia, wife of the Prophet, gave assistance to her relatives who were Jews. ${ }^{30}$ Once, in one of the festivals, Abdullah bin Omar said to his servant:" Don't forget our Jewish neighbor when you slaughter a sheep." Each time he entered or left the house he would repeat the same words. The servant replied: "Truly you have exceeded in your exhortations concerning this Jew." To which he replied: "Indeed, I heard the Prophet (PBUH) say, "The Angel Gabriel kept exhorting me with regard to (the rights of) neighbors until I thought that he would give them the right to inheritance." Thus, it is clear that neighbors be they of any religion, have rights over us. ${ }^{31}$ as a gesture of goodwill it was the practice of the Prophet (PBUH) to often visit the sick, as he visited a sick Jewish child of Medina.

Muslim-Jewish theological discourse was part and parcel of Medieval Muslim Medina as Abū Huraira narrates that "The People of the scripture used to read the Torah in Hebrew and explain it to the Muslims in Arabic. The Prophet (PBUH) advised his followers and said, " Do not believe the People of the Scripture and do not disbelieve them, but say, we believe in Allah and whatever has been revealed...(3:84)". ${ }^{32}$ Additionally, the Prophet advised companions acting as dignitaries to bear in mind cross cultural differences and intellectual status of the people as $\mathbf{M}^{\prime}$ āz bin Jabal was being sent by the Prophet (PBUH) to the people of Yemen he was told, "You are being sent to the People of the Book." 33 It shows that careful study of society and circumstances of invitee must be kept in mind while addressing any issue. 
Patterns of Peaceful Cooperation in lhyā' al- 'Ulūm, Volume 21, Issue 1,

Medieval Muslim Medina and Its (Jan-June 2021)

Relevance to the Present

Cross-cultural analysis requires an understanding of the prevalent cultural values and norms in a given society. ${ }^{34}$ When encountering inter-religious disputes, the Prophet sought help from Jewish scholars. The Prophet (PBUH) had a body of companions who were experts in the language of scriptures, other than Arabic, because some of them were religious leaders before embracing Islam. A case of a Jewish man and woman about fornication was reported to the Prophet (PBUH). On that occasion, Abdullah bin Salām bin Hārith (d.43A.H/663A.D), who had converted from Judaism to Islam, had been fully aware of Jewish religious scripture and law, and helped the Prophet (PBUH) in legal matters. ${ }^{35}$ Abdullah bin 'amr bin al-'Ās gained the knowledge from Qur'an and Torah, and he would recite each of the two books on alternate days. ${ }^{36}$

\section{Christians in Muslim Medina and religious engagements with them}

In addition to the Jews, the Prophet maintained harmonious relations with the Christians too, a relevant minority in Medina. Many of the companions of the Prophet were of Christian descent as Udaim al-Taghlabi, belonged to bani Taghlab (a Christian tribe). ${ }^{37}$ The Prophet advised his companions to deal amicably with Coptic (a branch of Christianity) as Maria, mother of Ibrahim, a son of the Prophet Muhammad (PBUH) belonged to her. ${ }^{38}$ Abu Rafay, Aslam, a freed slave of the Prophet was Coptic (Christian). ${ }^{39}$ Even after Islam became a massive empire, the companions of the Prophet continued to respect Christianity. The Prophet (PBUH) treated Christian dignitaries with utmost respect, as once the Prophet received a delegation of Christians in Medina from the region of Najran, (the greatest center of Christianity in Yemen), held dialogue, showed hospitality, they were allowed to offer their prayers at Masjid-e-Nabvi, and so they faced towards the east and prayed. ${ }^{40}$ Moreover, the most significant Charter of tolerance was granted by the Prophet of Islam to Christians. The Prophet (PBUH) sent a letter to the people of Najran in which he clearly mentioned Islam's pluralistic policy and wrote, "Security of God and his own pledge to the Christians of Najran and adjoining areas, their lives, religion, lands, wealth, places of worship and Churches will be protected. Priests will continue their religious duties and others in responsible positions will be allowed to carry out their duties with protection and no disturbance". ${ }^{41}$

\section{The presence of Abyssinian blacks in Muslim Medina}


Patterns of Peaceful Cooperation in lhyā' al- 'Ulūm, Volume 21, Issue 1,

Medieval Muslim Medina and Its (Jan-June 2021)

Relevance to the Present

Slavery was legitimated in pre-Islamic Arabia as Aslam Habashi, (from African origin) was a shepherded of a Jew of Medina before his conversion to Islam. ${ }^{42}$ Many of the Prophet's (PBUH) freed slaves were either fully or partially of African origin. The Prophet (PBUH) always had Abyssinians in his life both in times of ease and difficulties (from early childhood, to Prophet Hood till his demise). Therefore, the Prophet fostered social, cultural and religious ties with Abyssinia. At an early age the Prophet (PBUH) was looked after by an Abyssinian woman, Umm Aiman (Barkah). Many of his companions and some of the slaves he freed were from Abyssinia as Shuqran, ${ }^{43}$ Safinah, ${ }^{44}$ Abu Musarrah (or Abu Masrooh), and Ansah ${ }^{45}$ The Prophet maintained strong diplomatic relations with Abyssinia which allowed migrants from Makkah to live there. Negus (King of Abyssinia) arranged marriage of Umme Habiba with the Prophet. ${ }^{46}$ Negus and the Prophet exchanged gifts and good wishes. When Negus died in 9th Hijra/631 A.D, the Prophet conducted his funeral prayer from Medina. Including 16 women $^{47}$ about 83 people (excluding children) migrated from Makkah to Abyssinia in $615 \mathrm{AD}$, while 33 later returned. ${ }^{48}$ At the time of Hijra to Medina in 622 A.D about 70 -80 Muslims were already living in Abyssinia under the protection of Negus, Jafer bin Abi Talib (Ali's older brother) remained in Abyssinia for many years. During the stay in Abyssinia many children (male and female) were born there as among the male Muhammad bin Abi Huzaifa, ${ }^{49}$ Abdullah bin Ja'far, ${ }^{50}$ Abdullah bin al-Muttalib, ${ }^{51}$ and Mūsa bin Haris. ${ }^{52}$ Some of the female born in Abyssinia are Fatima bint Haris, Aaisha bint Haris, Zainab bint Haris, ${ }^{53}$ Amat bint Khalid, ${ }^{54}$ Zainab bint Abi Salmah, ${ }^{55}$ and Habiba bint Ubaidullah. ${ }^{56}$ Abyssinian emigrant Muslims came back to Arabia with the new language, ideas and understanding of African civilization. Later on, it is reported that Muslims in Medina used some medicines as ear drop which they brought from Abyssinia. ${ }^{57}$ When two or more cultures meet, they influence each other, therefore, during their stay in Abyssinia, Muslims not only developed many Abyssinian cultural traits but also left behind Islamic and Arabian influences on Abyssinians. Ja'far adopted some cultural traditions from Abyssinia and practiced them in Medina. Once the Prophet passed a verdict in the favour of Ja'far, he said nothing but rose to his feet and circled around the Prophet with the steps of a dancer. "Ja'far, what is this?" said the prophet. He answered: "It is that which I have seen the Abyssinians do in honour of their Kings. If ever the Negus gave a man a good reason to rejoice, that man would rise and dance about him. ${ }^{, 58}$ It seems that at least 
Patterns of Peaceful Cooperation in lhyā' al- 'Ulūm, Volume 21, Issue 1,

Medieval Muslim Medina and Its (Jan-June 2021)

Relevance to the Present

Abyssinian King and officials knew Arabic language as in the court of Negus; Ja'far's speech and Qur'anic verses related to miracle birth of Jesus were understood by Negus without any interpreter. Arab traders would export leather and woolen cloths to Abyssinia and import edibles. Due to mutual trade and presence of Abyssinian (slaves) in Arabian Peninsula, people of Medina started use of Abyssinian language in their daily lives. Arab children, who were born and bred in Abyssinia, returned to Medina, they were fluent in African language. The Prophet (PBUH) used "Sanah,Sanah" Abyssinian words, meaning good and beautiful ${ }^{59}$

Bilal (d. 23 A.H/644 A.D), his father Rabaha and mother Hamamah who were slaves had an Abyssinian family background. He was chosen for his fine voice to be the first to chant the words of the adhan calling muslims to prayer despite his imperfect pronunciation of Arabic. ${ }^{60}$ This gesture was nothing less than revolutionary for that time and place. Once Umar (R.A.) said "Abu Bakr (R.A.) is our leader, who freed our leader Bilal". ${ }^{61}$ Muslim blacks of Arabia were proud to see themselves first as Muslims before being black, another Abyssinian delegation came to Medina to see the Prophet (PBUH), he welcomed them whole-heartedly and personally participated in their hospitality and said that they held a special place for us (as they helped our companions in Abyssinia). Therefore, "I like to respect them and be hospitable towards them". ${ }^{62}$ The Islamic State of Medina always had friendly relations with Abyssinia for a long period of time. The Prophet Muhammad (PBUH) explicitly announced State policy and said that "Until and unless you are not attacked by the Abyssinians, you should not initiate the fighting" ${ }^{13}$ Adward Simpson and Kai Kresse write that, "The Christian hierarchy in Ethiopia maintained good relations with the Islamic regime in Egypt in order to retain its close links with the Coptic Church whose patriarch in Alexandria continued to appoint the bishop in Ethiopia until the 1950s". ${ }^{64}$ In conclusion, the Prophet (PBUH) with his grace extended a welcoming hand towards Abyssinian people and dignitaries.

\section{Zoroastrian based religious community in Muslim Medina}

Zoroastrians as a minority were also settled in Yemen, and paid Jizya. ${ }^{65}$ Zoroastrians are placed on an equal basis with the groups having divine books. While stating the status of Zoroastrians, the Prophet (PBUH) said, "Treat them as you treat People of the Book" "66 Some of the Prophet's companions belonged to Zoroastrians/Persian origins. Abu Abdullah, Salman 
Patterns of Peaceful Cooperation in lhyā' al- 'Ulūm, Volume 21, Issue 1, Medieval Muslim Medina and Its (Jan-June 2021)

Relevance to the Present

al Farsi (d. 35A.H/655A.D), one of the closest companion, was born in Ramhur muz (a village of Esfahan in Persia), in a Zoroastrian family, and then was attracted to Christianity. He was then sold to a Jew of the Banū Qurayzah before accepting Islam. ${ }^{67}$ In order to remove the bad feelings of migrants the Prophet integrated people of other backgrounds into his close family circle. About Salman Farsi said "Salman is one of us, the Prophet's housing". ${ }^{68}$ Abu Dumaira, ${ }^{69}$ and Ansah ${ }^{70}$, were Persian slaves who were freed by the Prophet. The Prophet (PBUH) used "Kakh, Kakh" Persian words meaning to stop. ${ }^{71}$ Abu Huraira (d. 57 A.H/676A.D), a companion of the Prophet was reported communicating in Persian with a Persian woman. ${ }^{72}$

\section{Romans in Medina}

Early historians mention Bilad al Rum (land of the Romans), because of its significance from Muslim perspectives. Although, in medieval Arabic times, the term Rum (Roman) represented a territory that lay to the north and west of the Islamic Near East and North Africa. ${ }^{73}$ Mariyya al-Qibtiyya's mother was from Byzantine. ${ }^{74}$ Suhaib (d. 38 A.H/658A.D) was brought up as a slave in Roman culture, so his non-Arabic dialect was dominant in his speech. ${ }^{75}$ Baqoom, a Roman origins expert carpenter of Medina was hired to make a pulpit for sermon of the Prophet (PBUH) ${ }^{76}$

\section{The Polytheists in Medina}

After the conquest of Makkah, a delegation of Banu Saqeef, (a polytheist tribe) came to visit the Prophet (PBUH) and he (PBUH) allowed them to pitch tents in Masjid-e-Nabavi. The Muslims questioned how the Prophet could allow such ritually impure people to stay in a Mosque. The Prophet (PBUH) replied that their ritual impurities are contained in them. Those impurities do not contaminate the area around them. ${ }^{77}$ Before the conquest of Makkah, Abu Sufyan (before accepting Islam), had come to the Prophet (PBUH) to review a treaty and he (PBUH) allowed him to enter Masjid-e-Nabwi. ${ }^{78}$ There was a severe drought in Makkah. People had no choice but to eat the flesh and bones of the dead. Abu Sufyan came to the Prophet (PBUH' and said, "You preach good treatment (towards relatives). Your relatives are dying of hunger. Please pray to Allah for rain. The Prophet prayed and then there was heavy rain"79 Samamah b.in Asal, (who had great respect for the Prophet (PBUH), stopped the supply of food from Najad, as a punishment for the Prophet's enemy. 
Patterns of Peaceful Cooperation in lhyā' al- 'Ulūm, Volume 21, Issue 1,

Medieval Muslim Medina and Its (Jan-June 2021)

Relevance to the Present

However, the Prophet (PBUH) forbade Samama to continue this punishment " ${ }^{80}$ Asma, daughter of Abū Bakr (R.A), accepted Islam after Treaty of Hudaibiyah, her non-Muslim mother Qutaila, visited Medina to see her. Asma (R.A.) refused to meet her. When she asked the Prophet (PBUH) regarding this, he advised her to treat her well ${ }^{81}$ According to Muslim Jurists it is essential for every Muslim to treat one's brother and sister well whatever his/her religion, and also help him/her when in need.

\section{The presence of Egypt's Coptic Christians community}

At present Egyptian Coptic Christians are the largest Christian minority in the Middle East. ${ }^{82}$ Many Coptic Christians were also part of early Muslim society. In the year 6 or 7/627-629 Muqawqis the governor of Alexandria sends Mariyya as a gift to the Prophet. Along with her, Muqawqis also sends hin her sister Sirin. Ma'bur, an old eunuch also accompanies these gifts. Mariyya al Qibtiyya and her sister converted to Islam but Ma'bur does not accept Islam until sometime later. The story of Mariyya in Islamic heritage advocates interfaith harmony between Muslims and Christians. Since the Prophet's son is born to a woman of Coptic heritage, the Muslims are now required to treat the Copts with the care and protection owed to their kin. Ibrahim's birth only strengthens the ancient bond between the Copts and Muslims originally based on the Egyptian Hagar's birthing of the Prophet Abraham's son Isma'il. ${ }^{83}$

\section{Concluding Remarks}

Islam prohibits discrimination based on class, ethnicity, and gender. The Prophet Muhammad (PBUH) embraced diversity and successfully transformed and refined a wild society into a civilized community and shaped leaders for a new civilization. How can Muslims build a pluralistic present and live in harmony in this hostile situation of mistrust and fear? Many fruitful lessons and non-confrontational methods can be learned from the rich Medieval Sirah heritage and literature. The Prophet (PBUH) not only held dialogue with people of other beliefs (cultures etc.) at his level but also permitted and encouraged his companions to hold similar dialogue at their respective levels. The early medieval Muslim community firmly believed in diversity and Muslim traders interacted with Ethiopian, Indian and Chinese commercially. The Prophet accorded Ethiopia special status. The Prophet (PBUH) sought harmonious relations with people from other faiths and 
Patterns of Peaceful Cooperation in lhyā' al- 'Ulūm, Volume 21, Issue 1, Medieval Muslim Medina and Its (Jan-June 2021)

Relevance to the Present

civilizations and treated Jews, Christians and Polytheists with the utmost dignity. To enhance communication between Muslims and others, the Prophet (PBUH) commanded his companions to study foreign languages. The Prophet ensured that his treaties must protect the rights of other religious minorities as obvious from Charter of Medina, and treaty with people of Najran. The relatively cordial relations between the different religious communities in Medina stemmed from a commercial rationale, from religious tolerance and from shared linguistic and cultural traits. Mass conversion occurred and many pre-existing customs were accommodated. Islam expounded tolerance and universalism. The Qur'an expressly condemned racism, tribalism and nationalism, while Muslim powers generally proved relatively tolerant of Jews, Christians and Zoroastrians. Islam is full of potential to live together peacefully and reconcile. The Prophetic teachings are firmly rooted in peace. We need deep understanding on how we can move forward while looking at the pluralistic past. Some misguided religious and political leaders try to bring people of different faiths into war, through twisted interpretations of religious scriptures for the sake of power and popularity. Despite the differences in culture, religion, country and continent, Muslim minority of Abyssinia lived peacefully in a Christian majority territory which proves that Muslims can live peacefully with any other (non) religion today. The Medina Charter reflects a vision of peace and is very relevant to the solution of current tensions existing among the Muslims, Jews, and Christians.

\section{References:}

1. Ibn Hasham. (2004). al Sirat al Nabawiyya. Beirut: Darul Khair p. 113 Vol. 1

2. Ibid Vol. 1 p. 62

3. Ibn Hasham Pp.51 \& 58 V.3

4. Ibid p.63 Vol.3

5. Mishkatul Masabih, bab almfakharat wl asabiyya p. 416

6. Ibn Hasham p.71 Vol.3

7. Ibn Athir, Izzuddin abul Hasan Ali b. Muhammad.(2012). Usudul Ghaba fi Marifat al Sahaba Beirut: Dar ibn Hazm p.13 (18)

8. Ibn Hasham p.72 Vol.4

9. Qạ̣i Ayaz b. Musa. (2002). Al-Shifa bi tariff-e-Huquq al Mustufa. Beirut: Dar Ibn Hazm p.49

10. Talib Hashami.(1991). Wfud Arab bargah-e-Nabwi mai, Lahore: Hira Publications p.14

11.Ibn Hasham p. 169 Vol.4

12.Ibn Hasham p.172 Vol.4

13. Nadvi, Mujibullah.(1986). Ahl Ktab Sahaba wa Tabiin. Pakistan, National Book Foundation p.8 


\section{Patterns of Peaceful Cooperation in lhyā' al- 'Ulūm, Volume 21, Issue 1, Medieval Muslim Medina and Its (Jan-June 2021) Relevance to the Present}

14.Ibn Hashim Vol. 3 p.152

15. Usudul Ghaba fi Marifat al Sahaba p.34 (94)

16.Ibn Hasham p. 147 Vol.2

17.Dr. Hameedullah.(2005). Islami Riyasat. Lahore: al-Faisal Nashiran p.124

18. Ibid

19.Ibn Hasham p.192 Vol.3

20.Ibn Hasham p.221 Vol.4

21. Abul Hasan, Ahmed b. Yahya b. Jabir al blazari.(2000).Futuhul Bulda. Beirut: Dar al kutub al Almiyah p. 281

22. Abu al Hasan, Ahmed b. Yahya b. Jabir al blazari.(2000).Futuhul Buldan Beirut: Dar al kutub al Almiyah p. 281

23. Muhammad Hamidullah.(1985). al Wasai'q al siyasiya. Berut: Dar al Nafaa's p.59

24. Ibid p.61

25. Sachedina, Abdulaziz (2001). The Islamic Roots of Democratic Pluralism. New York: Oxford University Press p.26

26. Al Bukhari, Muhammad bin Ismā'il. (1999). Sahih Al- Bukhari. Riyad: Darussalam. Bab 49, Hadith no 1311 p. 210.

27. Sahih Al- Bukhari. Hadith no 1312. NOTE: The same thing happened in Qadsiah, when the funeral of a Zimmi passed. Sahl b. Hunaif (R.A) and Qais b. Saad (R.A), stood up at once. A person objected saying, "This is the funeral of a Zimmi". They replied that a similar situation happened in the time of Prophet (PBUH) regarding a Jew and he (PBUH) said "After all, he (a Jew) is also a human- being."

28. Abu Ubaidullah al Qasim b. Salam.(NG). Kitabul Amwal. Qatar: Ahya al Turathul Islami p.643

29. Nadvi, Abdul Salam .(2004). The Ways of Sahabah (companions of the Prophet (PBUH). Tr. Muhammad Younus Qureshi. Karachi: Darul Ishaat p.430

30. Abu Ubaidullah al Qasim b. Salam.(NG). Kitabul Amwal. p.643

31. Abu Dawud, Sulaiman bin Ashas. (2007). Sunan -e- Abi Dawud. Bab no.134, Hadith No 5151, Riyad: Maktaba al Maarif p 931.

32. Sahih al-Bukhari. Kitab al tawheed, Book 93, Number 632

33. Sahih al- Bukhari Kitab al-Zakat Hadith no. 1496

34. Abdalla, Amr. (2000). "Principles of Islamic Interpersonal Conflict Intervention: A Search within Islam and Western Literature, in Journal of Law \& Religion 15,no.1.151-184

35. Muslim b. al-Hajjaj al-Qushari. (1987). Sahih Muslim, Kitab al Hudud no29 bab Rajm alyahud Hadith no. 1699. Vol. 3 pp.533-534

36. Dr. Hameedullah.(2005). Islami Riyasat Lahore:al-Faisal Nashran p.124

37. Usudul Ghaba fi Marifat al Sahaba p.23 (62)

38. Futuhul Buldan p. 134, Amr b. al Aas (R.A) conquered Egypt in 20 Hijra

39. Usudul Ghaba fi Marifat al Sahaba p.37 (118)

40.Ibn- Ishaq, (2004). The Life of Muhammad, tr. Guillaume A. Karachi: Oxford University Press, $p$ 271. NOTE: At the advent of Islam, Najran was situated in a fertile territory, inhabitants were one of the riches community in Arabia. Najran was a center for agriculture and was famous for silk textiles like many Arab cities, and also had leather and Arms factories.

41. Abu Yousuf, Yaqoob bin Ibrahim. (1979). Kitab al- Khiraj. Beirut: Darul Marifa p. 72

42. Usudul Ghaba p. 37 (115) 
Patterns of Peaceful Cooperation in lhyầ' al- 'Ulūm, Volume 21, Issue 1, Medieval Muslim Medina and Its (Jan-June 2021) Relevance to the Present

43. al Tabari, Abu Ja'far Muhammad b. Jarir.(2007). Tarikh al-Tabari. Beirut: Dar Ibn Kathir p.356 Vol.2, Shukhran was from Abyssinia and was given to the Prophet in his father's inheritance. According to some he was from Persia.

44.Ibid p.357 Vol.2, NOTE: Safinah was freed by Umm Salma with condition that he will serve the Prophet (PBUH). According to some his name was Mahran or Rabah. It is also said he was from Persia and his original name was Sabia b. marqia

45.Ibid NOTE: According to some his mother was Abyssinian and father was from Persia.

46. Ibn Hasham Vol.4 p.220

47.Ibid p.9 Vol.4

48. Ibid p.8 Vol.2

49.Ibn Hishsam p255 Vol 1 NOTE: His father was Abu Huzaifa b. Utbh b. Rabia b. Abd Shams and his mother was Sahlah bint Suhail b. Amr

50. Ibn Hisham p.255 Vol 1 NOTE: His father was Jaafar b. Abi Talib and mother was Asma bint Umais b. Noman

51.Ibn Hisham p257 Vol 1 NOTE: His father was Muttalib b. Azhar and mother was Ramala bint Abi Auf

52.Ibn Hisham p.258 Vol. 1 NOTE: His father was Haris b. Khaid and mother was Raitah bin Haris

53.Ibn Hisham p.258 Vol. 1 NOTE: Their father was Haris b. Khaid and mother was Raitah bin Haris

54.Ibn Hisham p.256 Vol.1 NOTE: Her father was Khalid b. Saīd bin al-'Ās and mother was Umaina (Humaina) bint Khalaf

55.Ibn Hisham p.258 Vol. 1 NOTE:H er father was Abu Salmah bin Abdul Asad and mother was Umm-e- Salama bint Abi Umayyah see Sīrat Ibn Hasham

56.Mowsoa Fiqhiya Kuwait. (2009)(Urdu) India: Islamic Fiqh Academy Vol. 2 p.575 NOTE: Her father was Ubaidullah bin Hajash, who became Christian in Abyssinia, and her mother, Umm Habiba, Ramla bint Abi ufyan remained Muslim and became wife of the Prophet (PBUH), Habiba she also narrated Hadith form the Prophet.

57. Ibn Hisham p224 Vol.4

58. Martin Lings. (1994). Muhammad (pbuh).Lahore: Suhail Academy p.282

59. Sahih al Bukhari. KItab al Jihad no. 56, bab no.177. Hadith no 3071 \& Kitab al Libas no. 77 bab. No 32 Hadith no.5845 \& Hadith 5832 bab 22 and Kitab al Adab. Bab 17 Hadith no 5993 \& Abu Sunan-e-Abi Dawud Hadith no. 4024. p.720

60. Cyril Glasse. (2002).The Concise Encyclopedia of Islam London: Stacey International p.88

61. Sahih al-Bukhari, Kitab al manaqib bab Manaqib Bilal Hadith 3754

62. Muhammad Tahir al-Qadri. (2007). Sirat al-Rasūl. Lahore: Minhajul Qur'an Publications Vol. 2, p. 485

63. Sunan Abi Dawood, Kitab al mlahim, bab al nahi an thyij altrk wal habsha, hadith no. 4302 p.770

64.Edward Simpson and Kai Kresse. (2007). Struggling with History. London: Hurst \& Company p.64

65.Futuhul Buldan p.50

66. Al-Sanani, Muhammad bin Ismail Al-Khlani.(1971). Subulus Salam. Beirut: Ahya Al-Turath al-Islami. Vol. 4, p. 47 \& 65 


\section{Patterns of Peaceful Cooperation in lhyā' al- 'Ulūm, Volume 21, Issue 1, Medieval Muslim Medina and Its (Jan-June 2021) Relevance to the Present}

67.Ludwig, W. Adamec .(2009). Historical Dictionary of Islam. Maryland: The Scarecrow Press pp. 276-277. \& According to Tarikh Tabari p.357 Vol.2 his Persian name was Mabh bin buzkhan b. dh dir

68. Ibn Saad. (1957). al Tabaqat Beirut: Dar Sadir Vol. 4, p83

69. Tarikh al-TabariVol.2 p. 358

70.Ibid p.357 Ansah his father was Persian and mother was Abysinian

71.Al Bukhari Kitab al Jihad 52, Hadith 306

72. Sunan-e- Abi Da'ūd, Kitab al Talaq, Hadīth no. 2277, Bab 35 p. 397.

73. Who are the Romans? The Definition of Bilad al-Rum (Land of the Romans) in Medieval Islamic Geographies by Koray Durak, in Journal of Intercultural Studies Vol. 31, No.3 June 2010, pp.285-298 Routledge Taylor \& Francis

74. Mariyya the Copt: gender, sex and heritage in the legacy of Muhammad's umm walad, by Aysha Hidayatullah, in 'Islam and Christian-Muslim Relations' Vol.21. No.3 July 2010, 221243 Routledge Tailor \& Francis p.235

75.Al-Qadri, Muhammad Tahir. Seerat al Rasul Vol.3 p.464

76. Usudul Ghaba fi Marifat al Sahaba p. 13 (18)

77. Al- Jassas, Abu Bakr, Ahmad bin Ali al-Razi, al-Hanafi (1335 Hijra). Ahkam-al Qur'an. Beirut: Darul Kitab al-Arabi Vol 3,p.88

78.Ibid Vol. 3, p.88

79. Mansoor Poori, Qazi Muhammad Sulaiman Salman(NG). Rahmatul - Alamin. Lahore: Shaikh Ghulam Ali Sons Vol. 1 p.265.

\section{Ibid}

81. Sahih Al-Bukhari. Bab no29. Hadith no 2620. p. 424.

82. Mariyya the Copt: gender, sex and heritage in the legacy of Muhammad's umm walad, by Aysha Hidayatullah, in 'Islam and Christian-Muslim Relations' Vol.21. No.3 July 2010, 221243 Routledge Tailor \& Francis p.223

83. To Die in Gain: Singing a Heavenly Citizenship among Egypt's Coptic Christians by Carolyn M. Ramzy, in Ethoos, Journal of Anthropology ISSN: 0014-1844, publisher Routledge Taylor \& Francis Group, Vol. 80:5, 2015 pp.649-670 